Those species which are now being driven from their habitats when houses are built on breeding grounds may well be able to survive an enforced move to another habitat. This may also apply to butterflies which are being deprived of their food as a result of the use of weedkillers. Most butterflies feed on common weeds, and so they are being driven from areas in which weedkillers are used extensively. Many species are being poisoned by these chemicals, and also by insecticides, which are harmful to a very wide range of insects. The development of more specific insecticides, which kill only particular insect pests, may cut down losses among butterflies. Like all insects, butterflies are able to build up resistance to insecticides, although the speed with which this occurs is dependent on many factors and can vary considerably from insect to insect. The cabbage white butterfly has developed immunity to DDT, and other species may well develop similar properties.

So far, the declining populations of British butterflies are not necessarily more spectacular than would be expected from the normal fluctuations from year to year. Even the decline of two-thirds in the numbers of the meadow brown may not be particularly ominous.

\section{Put it Down to Sunspots}

Is the July issue of the Canadian Journal of Botany, Dr Bruce Cumming, of the University of Westorn Ontario, claims that there is a correlation between periodicities in the germination of seeds and variations in the solar radio flux, which is an indicator of sunspot activity. Seeds of Chenopodium botrys were stored in darkness under controlled conditions of heat, humidity and pressure. Each week a cortain number were then removed for germination tests, and the percentage germinating was recorded. There was no correlation, apparently, between germination and humidity, pressure, magnetic intensity or the phases of the Moon. There was, however, a close relation between germina. tion frequency and the level of sunspot activity one week before the wetting of the seeds, although linear trends in solar flux and germination were opposite. At the same time, correlation between germination frequency and sunspot activity is expressed in the form of somewhat compressed diagrams-more than a hundred pairs of values have had to be represented on a horizontal scale only $12.5 \mathrm{~cm}$ across. Statistical analysis of periodic functions is necessarily complex, and many workers have emphasized the difficulties of comparing periodicities. It is therefore with caution as well as great interest that further details of Dr Cumming's work will be awaited.

\section{Chinese Fry}

THe white amur or grass carp occurs naturally in the rivers of Siberia and China, but it has been introduced into most of Asia where, raised in stews, it is an important commercial fish and source of protein. Unfortunately the fish do not reproduce naturally in southern latitudes. Much of south-east Asia depends for a supply of fry on China, where there is a considerable industry devoted to catching, sorting and exporting the young fish. Naturally enough, countries like Malaya and India would prefer-and may be obliged to have-a native supply of young fish instead of depending on Chinese sources. Moreover, the Chinese themselves are worried by existing arrangements, if only because they are leading to over-fishing of the rivers, notably the Yangtze Kiang and Si Kiang. Several attempts have been made, both in China and the importing countries, to induce successful spawning of pond reared fish by injecting female carp with fish pituitary gland extract. Apparently it is always the females that are infertile; the males seem to produce normal sperm no matter whore they are. In northern latitudes, Japan, Formosa, Manchuria and Northern India, the experiments were successful and in Cuttack in northern India, for example, hundreds of thousands of young grass carp are raised annually.

In more southern countries, however, the outlook is grimmer. Some recent work done in Malacca, at a latitude of $2^{\circ} 17^{\prime}$ N., by Hickling (Proc. Roy. Soc. Edin., B, \%0, 62; 1967) shows that it is impossible to induce spawning of fertile eggs. In Malacca, grass carp grow about three times faster than in natural habitats-Hickling's fish gained between 8 and 10 grammes a day, growing from $2 \mathrm{~g}$ to between 6 and 7 $\mathrm{kg}$, compared with a gain of $2.8 \mathrm{~g}$ a day by river carp in Siberia. This, of course, is what makes the grass carp such a valuable commercial fish. Furthermore, in Malacca the carp mature earlier and at a smaller size and, being so near the Equator in a climate without marked seasonal changes, they do not have a spawning cycle; some fish are ripe at all times of the year. The males shed active sperm, but the females fail to spawn. The ovaries fill with partially developed eggs which eventually atrophy. When Hickling injected female carp with pituitary extract from another cyprinid fish, Puntius gonionatus, the ovaries increased in size as the number of eggs increased, but the eggs themselves were still incompletely developed. When shed, none of these defective eggs was successfully fertilized.

Hickling believes that it is the lack of a climatic stimulus-a spring season with rising temperatures and increasing day length-that prevents egg development in Malacca. The synchrony of the breeding season of mammals with periods of increasing or decreasing light intensity is, of course, well documented. It would be intercsting to see if, by artificially altering temperature and day length, the carp could be induced to spawn in Malacca. But even if such experiments proved successful the cost would probably prohibit them as a commercial proposition. It seems that the unfortunate Malayans must remain dependent on an imported supply of carp fry.

\section{Sedimentology Congress}

\section{from a Correspondent}

THE seventh International Sedimentological Congress was held in the Universities of Reading and Edinburgh from August 11 to 15 under the general chairmanship of Professor J. H. Taylor, president of the International Association of Sedimentologists; nearly 450 delegates from 41 countries attended. The choice of two conference centres, several hundred miles apart, was justified on the grounds that both Reading and Edinburgh had excellent claims, the former because of its internationally renowned sedimentology laboratory, and the 